\section{Mycobacterium bovis Isolates from Tuberculous Lesions in Chadian Zebu Carcasses}

\author{
Colette Diguimbaye-Djaibé, ${ }^{* 1}$ Markus Hilty, $\dagger^{* 1}$ \\ Richard Ngandolo, ${ }^{*}$ Hassane H. Mahamat," Gaby \\ E. Pfyffer,‡ Franca Baggi,§ \\ Glyn Hewinson, $\uparrow$ Marcel Tanner, $\dagger$ \\ Jakob Zinsstag, $\dagger$ and Esther Schelling $\dagger$
}

This slaughterhouse study in Chad shows higher proportions of Mycobacterium bovis isolates among Mbororo than Arabe zebu cattle. Spoligotyping shows a homogenetic population structure for $M$. bovis and lack of spacer 30 , as were found in neighboring Cameroon and Nigeria. This finding suggests transborder and ongoing transmission between cattle.

Tn Chad, prevalences of tuberculin-positive cattle are $10.8 \%$ (95\% confidence interval [CI] $0.2 \%-1.4 \%$ ) in the east (Ouaddaï region) (1) and $16.9 \% \quad(95 \%$ CI $10.4 \%-23.5 \%$ ) in the west (Chari-Baguirmi and Kanem regions) (2). The latter comparative intradermal tuberculin study was conducted with 34 additional transhumant herds; a prevalence of $11.5 \%$ (CI $6.9 \%-18.5 \%$ ) was found when herds were considered as random effect in the model. More tuberculin reactors were found among Mbororo than Arab zebus ( $\mathrm{p}=0.02)$. In the slaughterhouse of Farcha in N'Djaména, 90\% of slaughtered cattle are of the Arab zebu breed, 7\% Mbororo zebu, and 3\% Kouri (3). Previous slaughterhouse studies showed that bovine tuberculosis (TB) is an important cause of condemnation (i.e., if a carcass is fully condemned, the whole carcass is destroyed [ $\approx 9 \%$ of all inspected cattle carcasses]) (4). A retrospective study on causes of condemnation after meat inspection showed that most carcasses with tuberculous lesions were detected from July to November and that more Mbororo cattle than other breeds had TB-like lesions (42/60 vs. 132/1,539) (5). The diagnosis of suspected bovine TB was based on sighting of typical macroscopic lesions of the organs during meat inspection.

*Laboratoire de Recherches Vétérinaires et Zootechniques de Farcha, N'Djaména, Chad; †Swiss Tropical Institute, Basel, Switzerland; łKantonsspital Luzern, Luzern, Switzerland; §National Centre for Mycobacteria, Zurich, Switzerland; and TVeterinary Laboratories Agency, Weybridge, United Kingdom
In Chad, until this study was undertaken, bovine TB was not confirmed by isolation or molecular characterization of the causative agent, Mycobacterium bovis. This organism is recognized as a zoonotic pathogen that infects many persons, particularly in the developing world. The highest prevalence of coinfection with bovine TB and HIV/AIDS is also in the developing world (6). Our study was aimed at isolating the first $M$. bovis isolates from specimens of Mbororo and Arab cattle in the newly setup mycobacteriology unit of the veterinary laboratory of Fracha, at characterizing the isolates with molecular methods, and at comparing the isolates with those from Cameroon (7).

\section{The Study}

From July 1 to August 31, 2002, a total of 727 of 10,000 cattle carcasses at the slaughterhouse of Farcha were condemned because of TB-like lesions on meat inspection. The overall prevalence of suspect lesions was $7.3 \%$. A significantly higher $(\mathrm{p}=0.04)$ proportion of lesions was found among Mbororo (8.2\%; 212/2,596) than Arab (7\%; $515 / 7,397)$ cattle (8). Lesions were mainly found in the lymph nodes and lungs (Table).

Specimens from 201 affected organs (lymph nodes, lungs, and liver) of 199 randomly selected carcasses were collected for further processing along with the following information: breed, sex, partial or total condemnation of the carcass, date of collection, and nature of specimen (8). The geographic origins of the cattle could not be evaluated as they were brought to the slaughterhouse by traders from local livestock markets. In the subsample of 199 animals, entire condemnation of the carcass in comparison to partial condemnation occurred more often among Mbororo than Arab cattle (19/75 vs. $\left.11 / 124, \chi^{2}, \mathrm{p}=0.002\right)$. A higher proportion of Mbororo cattle with bovine TB infection was also observed in Cameroon (9); this finding may indicate that Mbororo are more susceptible to M. bovis strains in the 2 Central African countries.

The 201 collected specimens were washed 3 times with sterile, distilled water. Tissue samples were cut into 5 or 6 pieces and put in a sterile plastic bag containing $10 \mathrm{~mL}$ sterile saline for homogenization. Samples were homogenized in a blender for $1 \mathrm{~min}$; this process was repeated 3 times. Ten milliliters of the suspension was decontaminated with $\mathrm{N}$-acetyl-L-cysteine sodium hydroxide $(0.5 \%$ NALC-2\% NaOH) (10), and $0.25 \mathrm{~mL}$ was injected onto 2 Lowenstein-Jensen slants, l containing glycerol (0.75\%) and 1 containing pyruvate $(0.6 \%)$. In addition, Middlebrook 7H9 medium containing oleic acid-albumindextrose-catalase and PANTA (polymyxin, amphotericin $\mathrm{B}$, nalidixic acid, trimethoprim, azlocillin) were injected

${ }^{1}$ These authors contributed equally to this study. 
Table. Specimens collected at the main slaughterhouse of N'Djaména, Chad, and specifications of the condemned carcasses

\begin{tabular}{|c|c|c|c|c|c|c|c|}
\hline \multirow[b]{2}{*}{ Organ/tissue } & \multirow[b]{2}{*}{$\mathrm{n}$} & \multicolumn{2}{|c|}{ Condemnation } & \multicolumn{2}{|c|}{ Breed } & \multicolumn{2}{|c|}{ Sex } \\
\hline & & Entire & Partial & Arab & Mbororo & Male & Female \\
\hline Lymph nodes & 116 & 17 & 99 & 67 & 49 & 8 & 108 \\
\hline Lungs & 75 & 13 & 62 & 51 & 24 & 1 & 74 \\
\hline Lungs and lymph nodes & 2 & 0 & 2 & 2 & 0 & 0 & 2 \\
\hline Liver & 5 & 0 & 5 & 4 & 1 & 0 & 5 \\
\hline Miliary tuberculosis & 1 & 0 & 1 & 0 & 1 & 0 & 1 \\
\hline Total & 199 & 30 & 169 & 124 & 75 & 9 & 190 \\
\hline
\end{tabular}

with $0.5 \mathrm{~mL}$ of the decontaminated suspension. Injected media were incubated at $37^{\circ} \mathrm{C}$ (without $\mathrm{CO}_{2}$ ) for 8 weeks. Growth of mycobacteria was confirmed by smear (stained by the Ziehl-Neelsen method) and acid-fast-positive colonies were subcultured. Three biochemical tests (11) were used to distinguish between $M$. tuberculosis complex and nontuberculous mycobacteria. Results were confirmed by real-time polymerase chain reaction (10).

Overall, $M$. bovis was isolated from more than one fourth of tissue samples and in $42 \%$ of all positive cultures. Significantly more $M$. bovis isolates were obtained from Mbororo zebu (30/75) than from Arab zebu (26/124) (p = $0.004)$. The difference remained significant when the type of condemnation and type of organ were included in a multivariate logistic regression model.

Spoligotyping, as described (12), was used as a tool for identifying $M$. bovis within the $M$. tuberculosis complex (lack of spacers 3, 9, 16, and 39-43) but also yielded insights into the epidemiology of $M$. bovis. In total, 12 different spoligotypes were found among the $55 \mathrm{M}$. bovis isolates; $51(92.7 \%)$ of 55 isolates were in 8 clusters $(\geq 2$ strains), which showed a homogenous population structure (Figure).

The predominant spoligotype in our study was SP1, with a cluster of 22 strains (40\%), as was the case in the study of Cameroon (7). SP1 that lacks spacer 30 corresponds to C1; 2 other clusters described in Cameroon (C1 and C5) were also found in Chad (SP2 and SP4). The finding of a high proportion of the same spoligotypes in the 2 countries indicates cross-border movement of cattle. A substantial degree of recent transmission of $M$. bovis strains among cattle is supported by the apparently high preva- lence (7\%) of TB-like lesions at the slaughterhouse in N'Djaména. However, the homogeneity of bovine strains could also be due to the absence of introduction of new spoligotypes in this particular area. Certain Cameroonian clusters (C7, C8, C9, and C10) (7) were only detected in the Adamaoua region, not in northern Cameroon or our Chadian study. The established measures of the Cameroonian government to prevent movement of cattle between the Adamaoua and the 2 northern regions appear effective. As to other neighboring countries, a recent publication describes $15 \mathrm{M}$. bovis isolates from cattle in Nigeria, and these also lack spacer 30 (13). This feature seems to be a characteristic of $M$. bovis strains in Central Africa.

Fifteen strains (8 from Arab and 7 from Mbororo zebu) were typed with the IS6110 restriction fragment length polymorphism (14) method, of which 11 and 4 isolates contained 2 or 1 band, respectively (data not shown). Therefore, Chadian $M$. bovis strains belong to low IS6110 copy number strains. Strains lacking spacer 30 had a band at $1.9 \mathrm{~kb}$, in accordance with the findings in Cameroon (7). No association was found between the number of bands and the cattle breed. IS6110 typing indicated 6 clusters and, thus, was of lower discriminatory power than spoligotyping. In a recent study, variable number of tandem repeat typing was more discriminatory for Chadian $M$. bovis strains than IS6110 and spoligotyping (15).

\section{Conclusions}

The first mycobacterial laboratory established in Chad confirmed bovine TB in Chadian herds by culturing and characterizing $M$. bovis. A high ongoing and cross-border transmission of $M$. bovis in cattle is suspected, but further

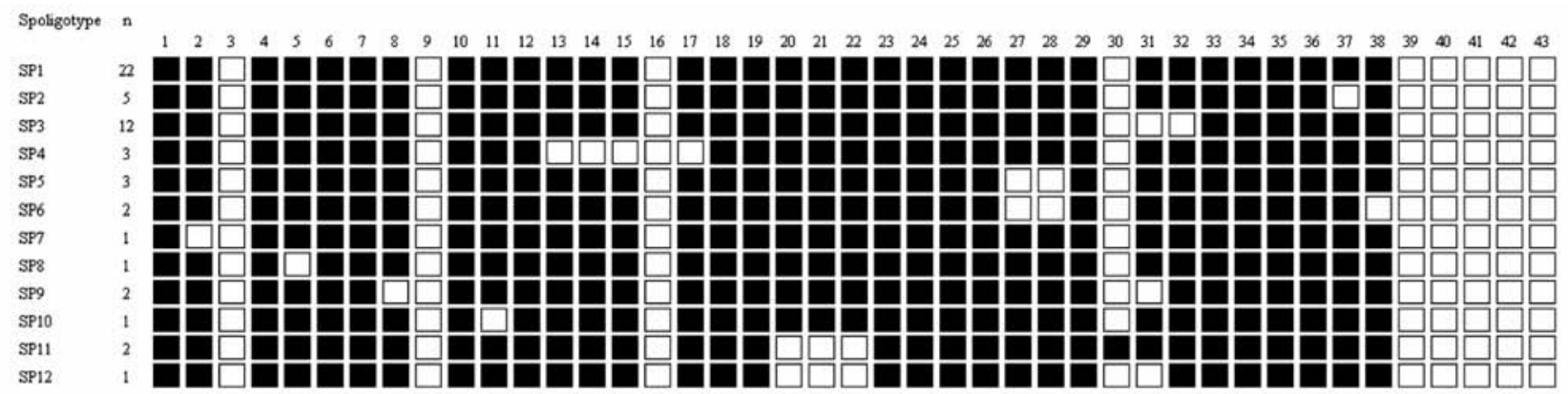

Figure. Spoligotypes obtained from 55 Mycobacterium bovis isolates from Chadian zebus. 
molecular epidemiology studies are needed to analyze its modes and risk factors. The apparently higher susceptibility of Mbororo zebus to M. bovis infection should be followed-up with immunologic assays.

\section{Acknowledgments}

We thank the technicians of the National Center for Mycobacteria, the Swiss Tropical Institute, and the "Laboratoire de Recherches Vétérinaires et Zootechniques de Farcha” who contributed to the project. We thank Véronique Vincent for complementary analyses and Steve Gordon for advice and discussion.

The Swiss National Science Foundation is acknowledged for financial support. This work received support from the National Centre of Competence in Research North-South IP-4.

Dr Diguimbaye is head of the human and animal TB unit at the Laboratoire de Recherches Vétérinaires et Zootechniques de Farcha in Chad. One of her research interests is the evaluation of new TB diagnostics.

\section{References}

1. Delafosse A, Goutard F, Thebaud E. Epidémiologie de la tuberculose et de la brucellose des bovins en zone péri-urbaine d’Abéché, Tchad. Revue d'élevage et de médecine vétérinaires des pays tropicaux. 2002;55:5-13.

2. Schelling E, Diguimbaye C, Daoud S, Daugla DM, Bidjeh K, Tanner $\mathrm{M}$, et al. La tuberculose causée par Mycobacterium bovis: résultats préliminaires obtenus chez les pasteurs nomades Foulbés et Arabes dans le Chari-Baguirmi au Tchad. Sempervira. 2000;8:44-55.

3. Ministère de l'Elevage. Rapport national sur les ressources zoo génétiques du Tchad. N’Djaména, Tchad: the Ministère; 2003. p. 1-196.

4. Maho A, Mbakasse RN, Boulbaye N. Causes de saisies aux abattoirs du Tchad oriental. LRVZ/F In: Actes des IIIèmes Journées AgroSylvo-Pastorales, 29/11 au 03/12/1997. N’Djaména, Tchad: Laboratoires de Recherches Vétérinaires et Zootechniques de Farcha; 1999.
5. Maho A, Bornarel P, Hendrix P. Rapport technique: abattage et motifs de saisie (dominantes pathologiques) aux abattoirs du Tchad: cas de N’Djaména, Ati, Bol, Mongo et Oum Hadjer. N’Djaména, Tchad: Laboratoires de Recherches Vétérinaires et Zootechniques de Farcha; 1994. p. 1-17.

6. Cosivi O, Grange JM, Daborn CJ, Raviglione MC, Fujikura T, Cousins D, et al. Zoonotic tuberculosis due to Mycobacterium bovis in developing countries. Emerg Infect Dis. 1998;4:59-70.

7. Njanpop-Lafourcade BM, Inwald J, Ostyn A, Durand B, Hughes S, Thorel MF, et al. Molecular typing of Mycobacterium bovis isolates from Cameroon. J Clin Microbiol. 2001;39:222-7.

8. Doutoum AM, Toko MA. Mycobactérioses bovines et saisies à l'abattoir de Farcha. N’Djaména: Institut Universitaire des Sciences et Techniques d'Abéché; 2002.

9. Nfi AN, Ndi C. Bovine tuberculosis at the Animal Research Antenna (ARZ) Bangangte, Western province, Cameroon. Cameroon Bulletin of Animal Health and Production in Africa. 1997;45:1-3.

10. Kraus G, Cleary T, Miller N, Seivright R, Young AK, Spruill G, et al. Rapid and specific detection of the Mycobacterium tuberculosis complex using fluorogenic probes and real-time PCR. Mol Cell Probes. 2001;15:375-83.

11. Kent PT, Kubica GP. Public health mycobacteriology—a guide for the level III laboratory. Atlanta: US Department of Health and Human Services; 1985.

12. Kamerbeek J, Schouls L, Kolk A, van Agterveld M, van Soolingen D, Kuijper S, et al. Simultaneous detection and strain differentiation of Mycobacterium tuberculosis for diagnosis and epidemiology. J Clin Microbiol. 1997;35:907-14.

13. Cadmus S, Palmer S, Okker M, Dale J, Gover K, Smith N, et al. Molecular analysis of human and bovine tubercle bacilli from a local setting in Nigeria. J Clin Microbiol. 2006;44:29-34.

14. van Embden JD, Cave MD, Crawford JT, Dale JW, Eisenach KD, Gicquel B, et al. Strain identification of Mycobacterium tuberculosis by DNA fingerprinting: recommendations for a standardized methodology. J Clin Microbiol. 1993;31:406-9.

15. Hilty M, Diguimbaye C, Schelling E, Baggi F, Tanner M, Zinsstag J. Evaluation of the discriminatory power of variable number tandem repeat (VNTR) typing of Mycobacterium bovis strains. Vet Microbiol. 2005;109:217-22.

Address for correspondence: Markus Hilty, Socinstrasse 57, PO Box, Swiss Tropical Institute, 4002 Basel, Switzerland; email: Markus.Hilty@ unibas.ch

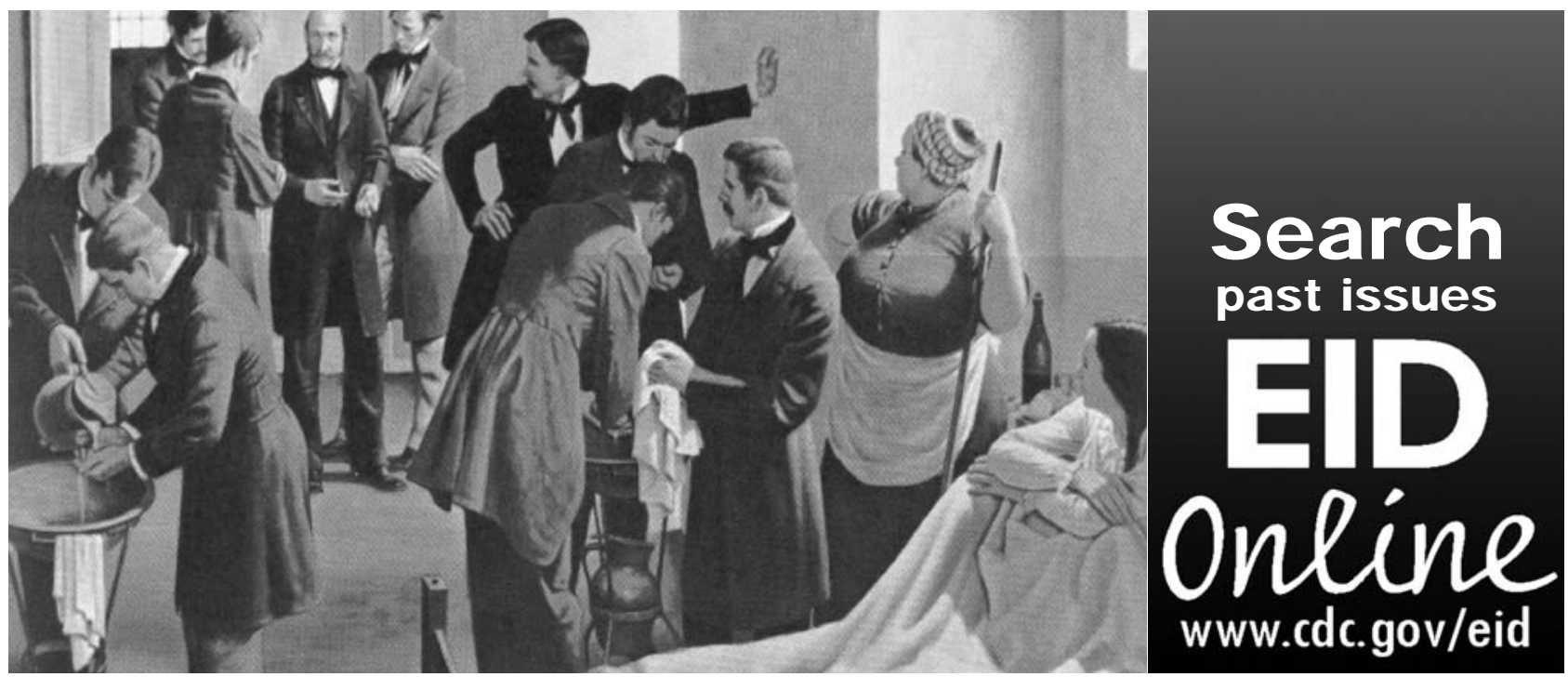

